\title{
Sternectomy for primary chondrosarcoma
}

\author{
Stéphane Collaud", Theresa Stork", Daniel Valdivia, Keita Tokuishi, Clemens Aigner \\ Department of Thoracic Surgery, Ruhrlandklinik, University of Duisburg-Essen, Essen, Germany \\ \#These authors contributed equally to this work. \\ Correspondence to: Clemens Aigner, MD, MBA. Professor of Thoracic Surgery, Head of Department of Thoracic Surgery, University Medicine Essen \\ - Ruhrlandklinik, Tueschener Weg 40, 45239 Essen, Germany. Email: clemens.aigner@rlk.uk-essen.de.
}

Submitted Jun 06, 2019. Accepted for publication Jun 14, 2019.

doi: $10.21037 /$ jtd.2019.06.41

View this article at: http://dx.doi.org/10.21037/jtd.2019.06.41

\section{Introduction}

The incidence of chondrosarcoma is $<0.5$ per million and year, accounting for the most frequent primary malignant chest wall tumor (1). Surgery plays a major role in the treatment of chondrosarcoma since chondrosarcoma is relatively insensitive to chemotherapy and radiation (2). Due to the large tumor size at diagnosis, extended chest wall resection is often necessary.

We describe the case of a 64-year-old patient, who presented with a 5 -month history of painful swelling of the left chest. A computed tomography (CT) of the chest was performed. It showed a well circumscribed partially calcified mass at the sternocostal junction on the left second rib with extension into the pectoralis major muscle and deeper into the mediastinum (Figure 1). The cardiac magnetic resonance imaging could exclude involvement of the myocardium (Figure 2). An open biopsy diagnosed a G2 chondrosarcoma. After presenting the case in the multidisciplinary sarcoma tumor board, upfront surgical resection was advocated.

\section{Surgical technique}

The patient was positioned supine. A left hemiclamshell skin incision was performed. Subcutaneous tissue and the left pectoralis muscle were divided to enter the chest in the third intercostal space (Figure 3). Excision of the biopsy site was performed (Figure 4). Digital intrathoracic exploration allowed assessment of tumor extension. Rib resection line was marked accordingly. Ribs were resected with a rib cutter for ribs 4, 3 and 2. First ribs and clavicles were sectioned with a Gigli saw. The sternum was transversally divided with the oscillating saw (Figure 5). The tumor was freed

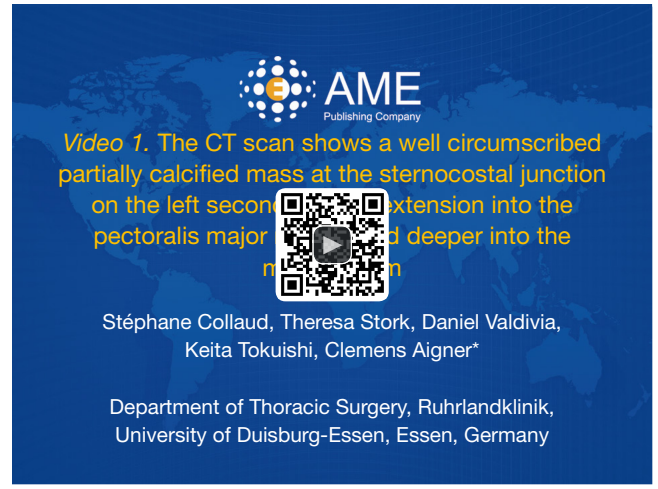

Figure 1 The CT scan shows a well circumscribed partially calcified mass at the sternocostal junction on the left second rib with extension into the pectoralis major muscle and deeper into the mediastinum (3).

Available online: http://www.asvide.com/watch/33053

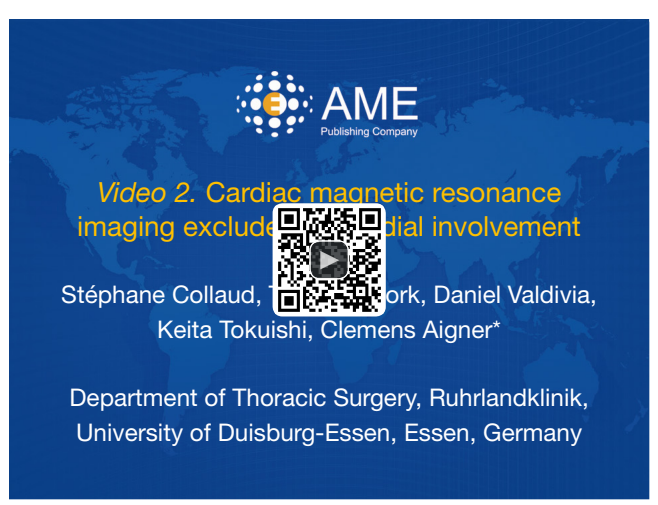

Figure 2 Cardiac magnetic resonance imaging exclude myocardial involvement (4).

Available online: http://www.asvide.com/watch/33054 


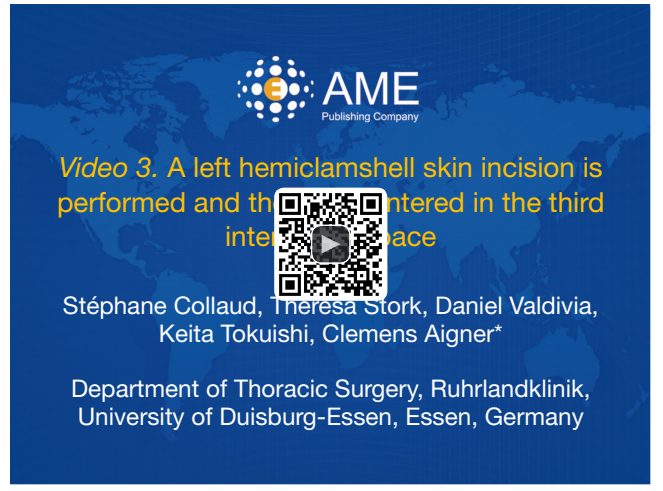

Figure $3 \mathrm{~A}$ left hemiclamshell skin incision is performed and the chest entered in the third intercostal space (5).

Available online: http://www.asvide.com/watch/33055

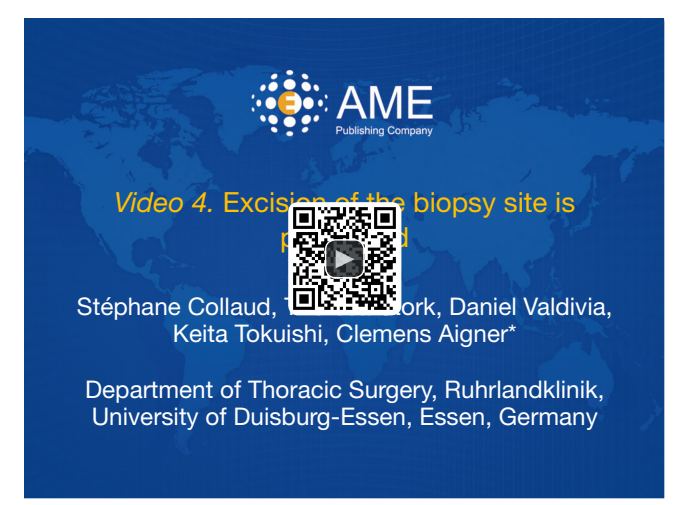

Figure 4 Excision of the biopsy site is performed (6). Available online: http://www.asvide.com/watch/33056

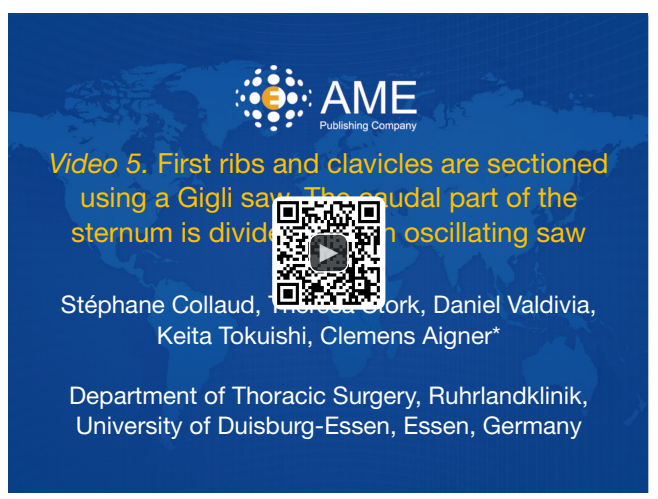

Figure 5 First ribs and clavicles are sectioned using a Gigli saw. The caudal part of the sternum is divided with an oscillating saw (7). Available online: http://www.asvide.com/watch/33057

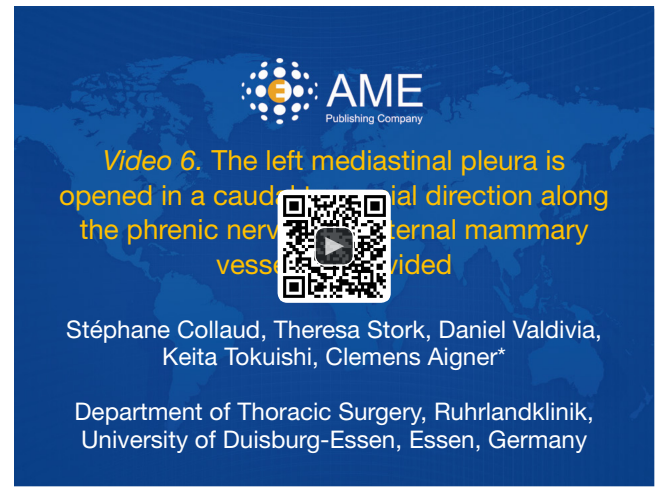

Figure 6 The left mediastinal pleura is opened in a caudal to cranial direction along the phrenic nerve. Left internal mammary vessels are divided (8).

Available online: http://www.asvide.com/watch/33058

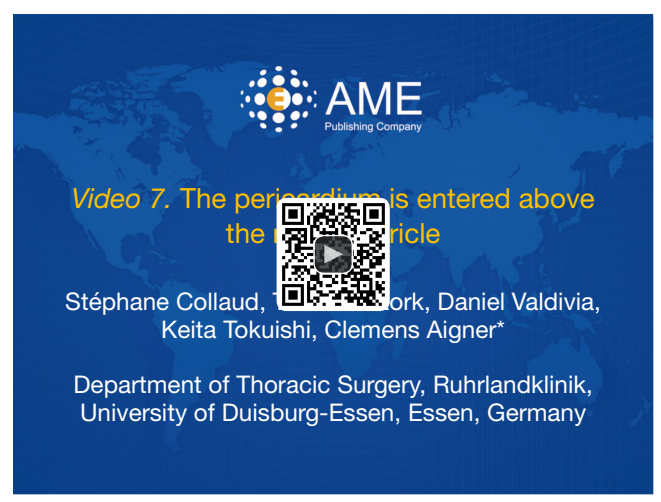

Figure 7 The pericardium is entered above the right ventricle (9). Available online: http://www.asvide.com/watch/33059

from the chest wall and was left pediculated on mediastinal structures. Left mediastinal pleura was opened in a caudal to cranial direction along the phrenic nerve. Left internal mammary vessels were divided (Figure 6). The pericardium was entered above the right ventricle (Figure 7). Pericardial section line followed the thoracic descending aorta on the left and the right atrium and superior vena cava on the right, respectively. Final dissection along the left brachiocephalic vein allowed en bloc tumor resection (Figure 8).

Pericardial reconstruction was performed using an absorbable polyglactin knitted mesh (VICRYL ${ }^{\circledR}$, Johnson \& Johnson Medical) (Figure 9). After the rib stumps were freed 


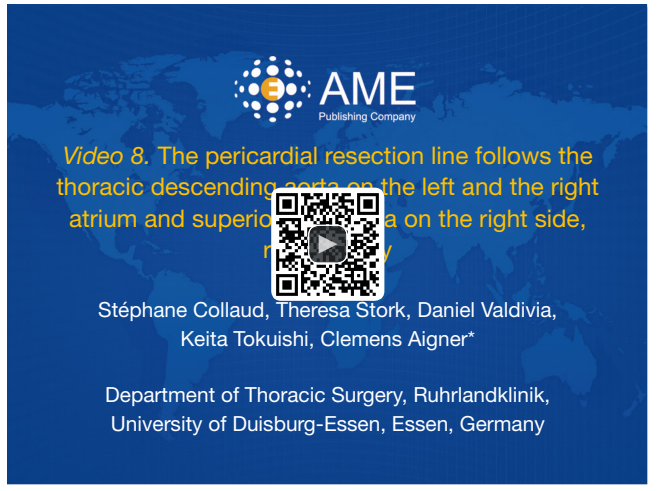

Figure 8 The pericardial resection line follows the thoracic descending aorta on the left and the right atrium and superior vena cava on the right side, respectively (10). Final dissection along the left brachiocephalic vein allows en-bloc tumor resection.

Available online: http://www.asvide.com/watch/33060

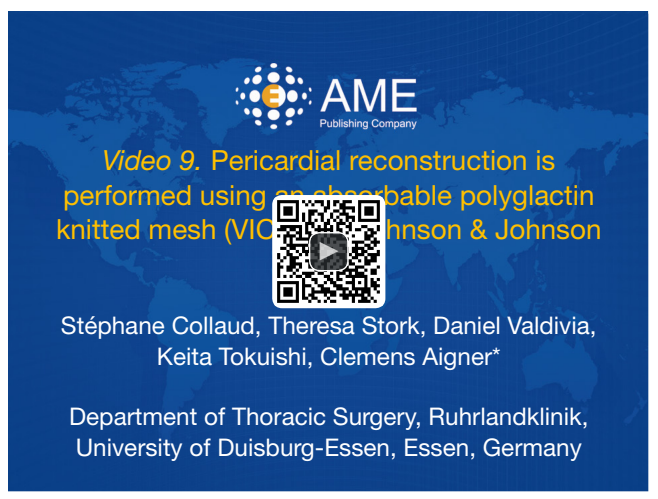

Figure 9 Pericardial reconstruction is performed using an absorbable polyglactin knitted mesh $\left(\mathrm{VICRYL}^{\circledR}\right.$, Johnson \& Johnson Medical) (11).

Available online: http://www.asvide.com/watch/33062

from intercostal muscles, the bony chest wall was stabilized using mouldable titanium bars and rib clips over ribs 1, 2 and 3 (STRATOS $^{\mathrm{TM}}$, MedExpert) (Figure 10). Pectoralis muscles were bilaterally mobilized away from the chest wall to cover the chest defect later on (Figure 11). Chest tubes were placed. A polytetrafluoroethylene patch (GORE$\mathrm{TEX}^{\circledR}$, W. L. Gore \& Associates) was anchored to the bony chest wall using non-resorbable sutures. Redon drainages were placed above the patch. The pectoralis muscle flaps were rotated and adapted together to cover the patch. The subcutaneous tissues and skin were closed (Figure 12).

Histopathologic examination of the specimen confirmed

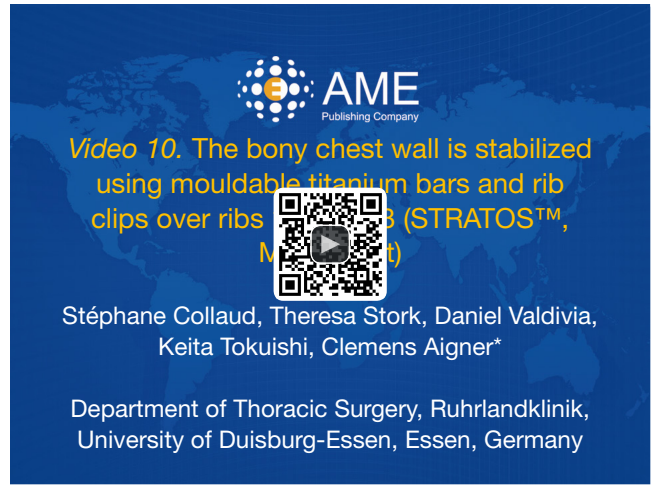

Figure 10 The bony chest wall is stabilized using mouldable titanium bars and rib clips over ribs 1, 2 and 3 (STRATOS ${ }^{\mathrm{TM}}$, MedExpert) (12).

Available online: http://www.asvide.com/watch/33063

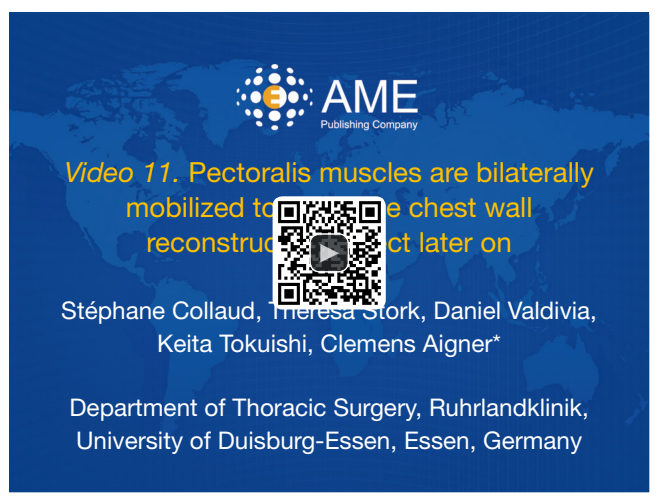

Figure 11 Pectoralis muscles are bilaterally mobilized to cover the chest wall reconstruction defect later on (13).

Available online: http://www.asvide.com/watch/33064

a G2 chondrosarcoma with microscopic complete resection (R0) with a circular safety margin of more than $1 \mathrm{~cm}$. Patient was discharged after an uneventful hospital stay. Range of motion of both upper extremities was grossly unlimited, even while lifting one-kilogram weights (Figure 13). Postoperative multidisciplinary case discussion at the sarcoma tumor board advocated follow-up with chest CT.

\section{Discussion}

Chest wall reconstruction after extended sternectomy for sarcoma can be challenging. In order to have efficient postoperative ventilatory mechanics, chest wall stability has to be obtained. Different prosthetic material can be used 


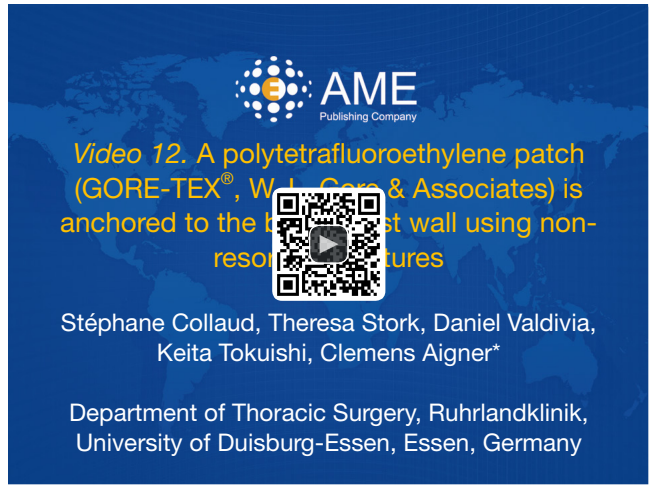

Figure 12 A polytetrafluoroethylene patch (GORE-TEX ${ }^{\circledR}$, W. L. Gore \& Associates) is anchored to the bony chest wall using nonresorbable sutures (14). The pectoralis muscle flaps are rotated and adapted together to cover the patch. The subcutaneous tissues and skin are closed.

Available online: http://www.asvide.com/watch/33065

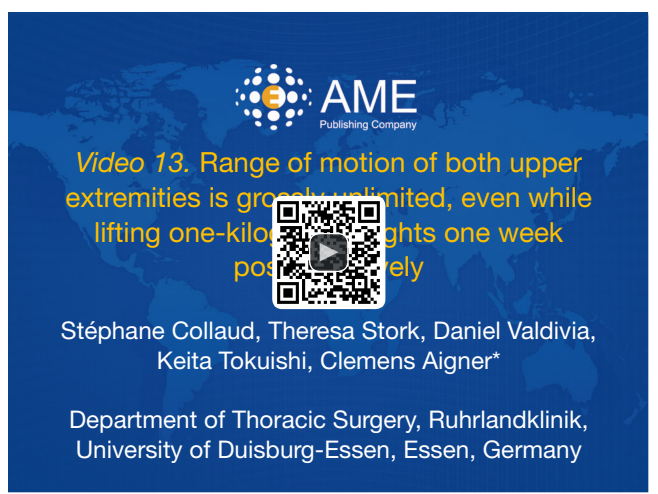

Figure 13 Range of motion of both upper extremities is grossly unlimited, even while lifting one-kilogram weights one week postoperatively (15).

Available online: http://www.asvide.com/watch/33066

and combined such as polyglactin knitted mesh $\left(\right.$ VICRYL $^{\circledR}$, Johnson \& Johnson Medical), polytetrafluoroethylene patch (GORE-TEX ${ }^{\oplus}$, W. L. Gore \& Associates) and mouldable titanium bars and rib clips (STRATOS ${ }^{\mathrm{TM}}$, MedXpert GmbH or THORIB $^{\circledR}$, NeuroFrance). Recently, a titanium sternal plate anchored to the ribs with reinforced sternal staple was developed to protect the mediastinal organs after sternectomy (TRYONIX ${ }^{\circledR}$, NeuroFrance). In case of soft tissue defect, muscle or musculocutaneous flaps (mainly pectoralis or latissimus dorsi flaps) can be used for covering prosthetic material.
Resection of the manubrium and bilateral medial clavicles is sometimes mandatory to obtain free resection margins. It is controversial whether the sternoclavicular joints should be reconstructed. Intuitively, reconstruction of the sternoclavicular joint seems recommended since sternoclavicular joints are the only true joints connecting the axial skeleton to the upper limbs. Due to the high degree of motion of the sternoclavicular joint, attempted fixation or fusion has often led to hardware loosening and migration (16). On the opposite, semi-rigid construct using mesh-bone cement sandwich mimicking the ligamentous biomechanical properties of the original sternoclavicular joints was successfully described (17). Here we decided not to reconstruct the sternoclavicular joints with grossly unlimited range of motion of both upper limbs as early as one week postoperative.

\section{Acknowledgments}

None.

\section{Footnote}

Conflicts of Interest: The authors have no conflicts of interest to declare.

Ethical Statement: The authors are accountable for all aspects of the work in ensuring that questions related to the accuracy or integrity of any part of the work are appropriately investigated and resolved. Written informed consent was obtained from the patient for publication of this manuscript and any accompanying images.

\section{References}

1 Burt M, Fulton M, Wessner-Dunlap S, et al. Primary bony and cartilaginous sarcomas of chest wall: results of therapy. Ann Thorac Surg 1992;54:226-32.

2 Bongiolatti S, Voltolini L, Borgianni S, et al. Short and long-term results of sternectomy for sternal tumours. J Thorac Dis 2017;9:4336-46.

3 Collaud S, Stork T, Valdivia D, et al. The CT scan shows a well circumscribed partially calcified mass at the sternocostal junction on the left second rib with extension into the pectoralis major muscle and deeper into the mediastinum. Asvide 2020;7:007. Available online: http:// www.asvide.com/watch/33053

4 Collaud S, Stork T, Valdivia D, et al. Cardiac magnetic 
resonance imaging exclude myocardial involvement. Asvide 2020;7:008. Available online: http://www.asvide. com/watch/33054

5 Collaud S, Stork T, Valdivia D, et al. A left hemiclamshell skin incision is performed and the chest entered in the third intercostal space. Asvide 2020;7:009. Available online: http://www.asvide.com/watch/33055

6 Collaud S, Stork T, Valdivia D, et al. Excision of the biopsy site is performed. Asvide 2020;7:010. Available online: http://www.asvide.com/watch/33056

7 Collaud S, Stork T, Valdivia D, et al. First ribs and clavicles are sectioned using a Gigli saw. The caudal part of the sternum is divided with an oscillating saw. Asvide 2020;7:011. Available online: http://www.asvide.com/ watch/33057

8 Collaud S, Stork T, Valdivia D, et al. The left mediastinal pleura is opened in a caudal to cranial direction along the phrenic nerve. Left internal mammary vessels are divided. Asvide 2020;7:012. Available online: http://www.asvide. $\mathrm{com} /$ watch/33058

9 Collaud S, Stork T, Valdivia D, et al. The pericardium is entered above the right ventricle. Asvide 2020;7:013. Available online: http://www.asvide.com/watch/33059

10 Collaud S, Stork T, Valdivia D, et al. The pericardial resection line follows the thoracic descending aorta on the left and the right atrium and superior vena cava on the right side, respectively. Asvide 2020;7:014. Available online: http://www.asvide.com/watch/33060

11 Collaud S, Stork T, Valdivia D, et al. Pericardial

Cite this article as: Collaud S, Stork T, Valdivia D, Tokuishi K, Aigner C. Sternectomy for primary chondrosarcoma. J Thorac Dis 2020;12(1):31-35. doi: 10.21037/jtd.2019.06.41 reconstruction is performed using an absorbable polyglactin knitted mesh (VICRYL ${ }^{\circledR}$, Johnson \& Johnson Medical). Asvide 2020;7:015. Available online: http://www. asvide.com/watch/33062

12 Collaud S, Stork T, Valdivia D, et al. The bony chest wall is stabilized using mouldable titanium bars and rib clips over ribs 1, 2 and 3 (STRATOS ${ }^{\mathrm{TM}}$, MedExpert). Asvide 2020;7:016. Available online: http://www.asvide.com/ watch/33063

13 Collaud S, Stork T, Valdivia D, et al. Pectoralis muscles are bilaterally mobilized to cover the chest wall reconstruction defect later on. Asvide 2020;7:017. Available online: http:// www.asvide.com/watch/33064

14 Collaud S, Stork T, Valdivia D, et al. A polytetrafluoroethylene patch $\left(\mathrm{GORE}-\mathrm{TEX}^{\circledR}, \mathrm{W}\right.$. L. Gore \& Associates) is anchored to the bony chest wall using non-resorbable sutures. Asvide 2020;7:018. Available online: http://www.asvide.com/watch/33065

15 Collaud S, Stork T, Valdivia D, et al. Range of motion of both upper extremities is grossly unlimited, even while lifting one-kilogram weights one week postoperatively. Asvide 2020;7:019. Available online: http://www.asvide. com/watch/33066

16 Rockwood CA, Matsen FA. The Shoulder. Vol. 1. Philadelphia Saunders 1990.

17 Collaud S, Pfofe D, Decurtins M, et al. Mesh-bone cement sandwich for sternal and sternoclavicular joint reconstruction. Eur J Cardiothorac Surg 2013;43:643-5. 